\title{
Stem Reserve Mobilization in Relation to Yield under Different Drought and High Temperature Stress Conditions in Wheat (Triticum aestivum L.) Genotypes
}

\author{
Kirpa Ram*, Rajkumar, Sunita and Renu Munjal \\ Department of Botany and Plant Physiology, CCS Haryana Agricultural University, \\ Hisar (HRY)-125004, India \\ *Corresponding author
}

\section{Key words \\ Wheat, Drought, High temperature and stem reserve mobilization \\ Article Info \\ Accepted: \\ 30 March 2018 \\ Available Online: \\ 10 April 2018}

A B S T R A C T

Pre-anthesis carbon accumulation in stem as reserve material an important source of mobilization during grain development stage (post anthesis) and directly influenced by drought and high temperature. The effect of different drought and high temperature conditions on stem reserve mobilization in relation to yield in wheat genotypes, viz., AKAW-3717, C-306, DHTW-60, HD-2967, HTW-11, KUNDAN, WH-730 and WH-1105 was studied during rabi season of mid-November to April, 2015-16 and 2016-17 in randomized block design with three replications. For control (irrigated) and droughtstressed condition, genotypes were sown at optimum planting date (timely sown), while for heat-stressed experiment sowing date was delayed by one month from the date of timely sown. Faster mobilization in accumulated dry matter was observed in all tested genotypes with increasing drought intensity in combination with high temperature both in peduncle and penultimate internodes. Under delayed sowing with combination of different drought condition, faster remobilization was observed in genotype DHTW-60, HD-2967 followed by WH-1105 and genotype AKAW-3717 had minimum remobilization value under all tested environment. The genotypes were found with high reserve mobilization value showed yield stability under all drought and high temperature environment. However, stem reserves mobilization (SRM) for grain filling time had great importance because current photosynthetic source that are mobilized to grain at post grain filling period and stress condition.

\section{Introduction}

Carbon requirements for grain filling in wheat are mainly from current assimilation by photosynthesis and remobilization of reserves from the stems (Yang et al., 2000). Remobilization of assimilates is an active process that involves translocation of stored reserves from stems and sheaths to grains
(Gupta et al., 2015). Stem reserves contribute 20 to $40 \%$ weight of the grain in non-stressed condition (Vignjevic et al., 2015) and this can be up to $70 \%$ under stressed conditions during grain filling (Rebetzke et al., 2008). Drought and high temperature induced earlier mobilization of non-structural reserve carbohydrates from stem and leaf sheaths, which provided a greater proportion of grain 
dry weight at maturity. It can account for 70$92 \%$ of grain dry matter, under conditions of drought (Yang et al., 2002; Pradhan et al., 2012). Accumulation of photosynthetic products depends on the environmental conditions, and it starts from internode elongation and continue up to grain filling stage in wheat (Dreccer et al., 2009). Heat (Wang et al., 2012) or water stress (Ehdaie et al., 2008; Gupta et al., 2011) can reduce water soluble carbohydrates and its mobilization to the grain growth.

But under heat stress, plants can only partially compensate for reduced stem carbohydrates content by increasing mobilization efficiency (Wang et al., 2012). Mobilization of photosynthate (water soluble carbohydrates) from the upper part of stem (such as peduncle and penultimate internode) appears to start at 21 DAA (days after anthesis) when the grain is about one third of its final mass.

However, such mobilization is started earlier at 10 DAA from the lower part of stem through peduncle in wheat (Ehdaie et al., 2006, 2008). There is a strong positive correlation between stem dry matter and stem WSC content, which suggests that postanthesis changes in stem dry weight in wheat could be an effective indirect method to estimate the amount of stem reserves accumulated and mobilized to grain (Ehdaie et al., 2008).

\section{Materials and Methods}

\section{Raising of crop and plant material}

Presents study was carried out in field and laboratory of Wheat and Barley section, Department of Genetics and Plant Breeding, College of Agriculture, CCS HAU, Hisar in winter season of mid-November to April, 2015-16 and 2016-17 with eight selected wheat genotype viz., AKAW-3717, C-306,
DHTW-60, HD-2967, HTW-11, Kundan, WH-730 and WH-1105. In control (irrigated) and drought-stressed experiments (with presowing irrigation only), genotypes were sown at optimum planting date, while for heatstressed experiment sowing date was delayed.

\section{Treatments}

Drought conditions was achieved by withholding the irrigation at different stages (40 days after sowing (DAS), 80 DAS, 40+80 DAS (Both at 40 and 80 days after sowing) and for complete drought no irrigation was given throughout the year).

Timely sowing was done on 17 November, 2015 and 13 November, 2016; late sowing on 14 December, 2015 and 16 December, 2016 and very late sowing 13 January, 2016 and 11 January, 2017.

\section{Stem reserve mobilization}

Stem reserve mobilization was calculated by the method suggested by Cox et al., (1986). Five stems (penultimate and peduncle without spike) from randomly selected plants from each plot at anthesis and maturity were separated into penultimate and peduncle and were dried in an oven at $80{ }^{\circ} \mathrm{C}$ for $72 \mathrm{hrs}$. The weight of stem parts was recorded with the analytical balance (Afcoset, ER-200A) and stem reserve mobilization was calculated using following formula.

$$
\operatorname{SRM}(\%)=\frac{\text { DMSHT (Ant) }- \text { DMSHT (Mat) }}{\text { DMSHT (Ant) }} \times 100
$$

SRM is stem reserve mobilization (g/plant); DMSHT (Ant) is above-ground dry matter of stem parts at anthesis stage (g); DMSHT (Mat) is aboveground dry matter of stem parts at maturity stage (g). SRM from stem part (penultimate and peduncle) was calculated separately. 


\section{Grain yield (g) per square meter}

Grain yield was recorded after harvesting and threshing the plants in per meter square. The threshed grains were cleaned and yield was recorded in gram.

\section{Results and Discussion}

\section{Stem reserve mobilization $(\%)$}

Stem reserve mobilization (\%) in peduncle and penultimate internode recorded under different drought and delayed sowing condition shown in Table 1 and 2.

\section{Peduncle reserve mobilization}

Application of drought showed faster remobilization in timely, late and very late sown conditions and highest stem reserve mobilization (Table 1) was found in complete drought situation $(29.1 \%)$ under very late sown condition followed by late sown drought condition $(24.2 \%)$ whereas lowest stem reserve mobilization was observed in control (irrigated) $(20.2 \%)$ under timely sown condition.

Average stem reserve mobilization in peduncle for different drought stress condition ranged from 13.3 to $24.9 \%$ (timely sown), 16.7 to $29.7 \%$ (late sown) and 21.3 to $34.8 \%$ (very late sown). The drought situation of D40+D65 and complete drought resulted significant maximum stem reserve mobilization 24.1 and $24.9 \%$ (timely sown), 28.4 and $29.7 \%$ (late sown) and 33.4 and 34.8 $\%$ (very late sown) respectively. Significant difference was observed in peduncle for reserve mobilization in all genotypes and different drought stress environments. Significant difference was observed among genotypes under timely sown, late sown and very late sown condition. Average peduncle reserve mobilization for genotypes ranged from 16.0 to 25.2 (timely sown), 19.5 to 30.0 $\%$ (late sown) and 24.3 to $34.5 \%$ (very late sown). Genotype WH-1105 (25.2\%) followed by HD-2967 (22.7 \%) had highest stem reserve mobilization under timely sown condition. Combined effects of heat and drought stress showed that DHTW-60 (30.0 $\%)$ and HD-2967 (27.7 \%) followed by WH$1105(25.6 \%)$ had high peduncle reserve mobilization under late sown condition and genotypes DHTW-60 (34.5 \%) and HD-2967 (33.2\%) followed by HTW-11 (30.6\%) under very late sown condition.

\section{Penultimate internode reserve mobilization}

Table 2 showed significant penultimate internode remobilization in all genotypes under drought stress and delayed sown condition.

Average penultimate internode reserve mobilization for different drought stress condition varied between 6.6 to $15.1 \%$ (timely sown), 10.2 to $19.2 \%$ (late sown) and 15.7 to $25.3 \%$ (very late sown). The drought situation of D40+D65 and complete drought resulted significantly highest in penultimate internode reserve mobilization 14.1 and 15.1 $\%$ (timely sown), 18.4 and $19.2 \%$ (late sown) and 24.0 and $25.3 \%$ (very late sown) respectively. Significant difference was observed for penultimate internode reserve mobilization in all genotypes under different drought stress condition.

Interaction of drought and genotypes was found significant under timely sown, late sown and very late sown condition. Average penultimate internode reserve mobilization for genotypes varied from 8.9 to $14.8 \%$ (timely sown), 10.4 to $20.4 \%$ (late sown) and 16.1 to $26.8 \%$ (very late sown). Genotype WH-1105 (14.8\%) followed by HD-2967 (14.1\%) had highest stem reserve mobilization under timely sown condition. 
Table.1 Response of wheat genotypes to drought and high temperature for stem reserve mobilization (\%) in peduncle under timely, late and very late sown conditions

\begin{tabular}{|c|c|c|c|c|c|c|c|c|c|c|c|c|c|c|c|c|c|c|}
\hline \multirow{3}{*}{ Genotypes } & \multicolumn{6}{|c|}{ Timely sown } & \multicolumn{6}{|c|}{ Late sown } & \multicolumn{6}{|c|}{ Very late sown } \\
\hline & \multirow[t]{2}{*}{ Control } & \multicolumn{4}{|c|}{ Time of drought application } & \multirow{2}{*}{$\begin{array}{c}\text { Mean } \\
\text { (G) }\end{array}$} & \multirow[t]{2}{*}{ Control } & \multicolumn{4}{|c|}{ Time of drought application } & \multirow{2}{*}{$\begin{array}{c}\text { Mean } \\
\text { (G) }\end{array}$} & \multirow[t]{2}{*}{ Control } & \multicolumn{4}{|c|}{ Time of drought application } & \multirow{2}{*}{$\begin{array}{c}\text { Mean } \\
\text { (G) }\end{array}$} \\
\hline & & D40 & D65 & D40+D65 & DR & & & D40 & D65 & D40+D65 & DR & & & D40 & D65 & D40+D65 & DR & \\
\hline AKAW 3717 & 9.1 & 13.6 & 17.0 & 19.7 & 20.7 & 16.0 & 12.5 & 16.7 & 20.2 & 23.4 & 24.9 & 19.5 & 15.8 & 20.1 & 26.2 & 29.4 & 30.0 & 24.3 \\
\hline C-306 & 11.6 & 16.1 & 20.1 & 23.1 & 23.9 & 19.0 & 15.1 & 18.8 & 22.9 & 26.4 & 27.4 & 22.1 & 17.1 & 21.5 & 27.9 & 30.0 & 31.4 & 25.6 \\
\hline DHTW-60 & 16.0 & 19.9 & 23.7 & 26.4 & 27.3 & 22.7 & 21.6 & 27.2 & 31.7 & 34.0 & 35.5 & 30.0 & 26.7 & 31.6 & 35.1 & 38.8 & 40.2 & 34.5 \\
\hline HD-2967 & 17.1 & 20.8 & 24.5 & 27.2 & 28.0 & 23.5 & 19.8 & 23.9 & 29.0 & 32.0 & 33.6 & 27.7 & 26.4 & 30.1 & 34.5 & 37.0 & 38.1 & 33.2 \\
\hline HTW-11 & 11.2 & 15.5 & 18.9 & 22.0 & 22.3 & 18.0 & 16.8 & 21.6 & 25.1 & 28.9 & 30.4 & 24.6 & 23.3 & 27.7 & 31.1 & 34.5 & 36.5 & 30.6 \\
\hline KUNDAN & 13.7 & 17.3 & 21.6 & 24.6 & 25.7 & 20.6 & 16.1 & 20.5 & 24.7 & 27.7 & 28.8 & 23.6 & 20.9 & 25.6 & 29.5 & 32.6 & 33.9 & 28.5 \\
\hline WH-730 & 10.0 & 13.8 & 17.6 & 20.2 & 20.8 & 16.5 & 13.3 & 17.3 & 21.3 & 24.9 & 25.8 & 20.5 & 18.9 & 23.2 & 28.3 & 31.5 & 32.7 & 26.9 \\
\hline WH-1105 & 17.7 & 22.4 & 26.2 & 29.2 & 30.6 & 25.2 & 18.0 & 22.1 & 26.5 & 29.7 & 31.5 & 25.6 & 21.6 & 26.4 & 30.2 & 33.0 & 35.5 & 29.3 \\
\hline Mean (D) & 13.3 & 17.4 & 21.2 & 24.1 & 24.9 & 20.2 & 16.7 & 21.0 & 25.2 & 28.4 & 29.7 & 24.2 & 21.3 & 25.8 & 30.4 & 33.4 & 34.8 & 29.1 \\
\hline $\mathrm{CD}$ at $5 \%$ & & $\mathbf{D}=$ & 36, G & 1.46, DxG= & & & & $\mathbf{D}=$ & $42, \mathrm{G}=$ & 1.23, DxG = & & & & $\mathbf{D}=$ & 49, G & $1.50, \mathrm{DxG}$ & & \\
\hline
\end{tabular}

D40- Drought at 40 days after sowing (DAS), D65- Drought at 65 DAS, D40+D65- Drought both at 40 and 65 DAS, DR- Complete drought, G-Genotypes and D- Drought

Table.2 Response of wheat genotypes to drought and high temperature for stem reserve mobilization (\%) in penultimate internode under timely, late and very late sown conditions

\begin{tabular}{|c|c|c|c|c|c|c|c|c|c|c|c|c|c|c|c|c|c|c|}
\hline \multirow[t]{3}{*}{ Genotypes } & \multicolumn{6}{|c|}{ Timely sown } & \multicolumn{6}{|c|}{ Late sown } & \multicolumn{6}{|c|}{ Very late sown } \\
\hline & \multirow[t]{2}{*}{ Control } & \multicolumn{4}{|c|}{ Time of drought application } & \multirow{2}{*}{$\begin{array}{l}\text { Mean } \\
\text { (G) }\end{array}$} & \multirow[t]{2}{*}{ Control } & \multicolumn{4}{|c|}{ Time of drought application } & \multirow{2}{*}{$\begin{array}{c}\text { Mean } \\
\text { (G) }\end{array}$} & \multirow[t]{2}{*}{ Control } & \multicolumn{4}{|c|}{ Time of drought application } & \multirow{2}{*}{$\begin{array}{l}\text { Mean } \\
\text { (G) }\end{array}$} \\
\hline & & D40 & D65 & D40+D65 & DR & & & D40 & D65 & D40+D65 & DR & & & D40 & D65 & D40+D65 & DR & \\
\hline AKA W 3717 & 3.8 & 7.6 & 9.5 & 11.6 & 12.2 & 8.9 & 5.4 & 9.2 & 11.9 & 13.7 & 13.7 & 10.8 & 11.1 & 14.7 & 16.7 & 18.5 & 19.7 & 16.1 \\
\hline C-306 & 5.9 & 9.5 & 11.9 & 13.1 & 14.5 & 11.0 & 9.0 & 12.3 & 14.0 & 15.8 & 16.9 & 13.6 & 12.2 & 15.0 & 17.5 & 19.4 & 20.8 & 17.0 \\
\hline DHTW-60 & 8.2 & 11.1 & 13.5 & 15.5 & 16.2 & 12.9 & 14.8 & 18.0 & 21.3 & 23.6 & 24.3 & 20.4 & 21.7 & 25.3 & 27.1 & 29.1 & 30.9 & 26.8 \\
\hline HD-2967 & 9.3 & 12.1 & 14.7 & 16.6 & 17.9 & 14.1 & 13.5 & 17.7 & 19.5 & 22.2 & 23.4 & 19.3 & 20.6 & 24.4 & 26.1 & 28.8 & 29.4 & 25.9 \\
\hline HTW-11 & 4.7 & 7.9 & 10.8 & 12.6 & 13.4 & 9.9 & 10.5 & 14.4 & 16.7 & 19.4 & 20.3 & 16.3 & 16.9 & 21.4 & 25.3 & 27.0 & 28.5 & 23.8 \\
\hline KUNDAN & 6.7 & 10.1 & 12.9 & 14.5 & 15.3 & 11.9 & 9.9 & 13.7 & 15.5 & 17.2 & 18.8 & $\mathbf{1 5 . 0}$ & 14.1 & 17.0 & 20.2 & 23.8 & 24.5 & 19.9 \\
\hline WH-730 & 4.4 & 7.8 & 9.7 & 12.0 & 12.7 & 9.3 & 6.5 & 10.3 & 12.4 & 14.8 & 15.1 & 11.8 & 13.3 & 16.4 & 18.8 & 20.5 & 21.9 & 18.2 \\
\hline WH-1105 & 9.9 & 13.0 & 15.4 & 17.1 & 18.7 & 14.8 & 11.9 & 15.6 & 18.0 & 20.4 & 21.1 & 17.4 & 15.8 & 19.3 & 22.1 & 24.7 & 26.6 & 21.7 \\
\hline Mean (D) & 6.6 & 9.9 & 12.3 & 14.1 & 15.1 & 11.6 & 10.2 & 13.9 & 16.2 & 18.4 & 19.2 & 15.6 & 15.7 & 19.2 & 21.7 & 24.0 & 25.3 & 21.2 \\
\hline CD at $5 \%$ & & $\mathbf{D}=$ & $.24, \mathrm{G}$ & 1.31, DxG= & & & & $\mathbf{D}=$ & $27, \mathrm{G}$ & 1.34, DxG= & & & & $\mathbf{D}=$ & 32, G & 1.41, DxG= & & \\
\hline
\end{tabular}

D40- Drought at 40 days after sowing (DAS), D65- Drought at 65 DAS, D40+D65- Drought both at 40 and 65 DAS, DR- Complete drought, G-Genotypes and D- Drought 
Table.3 Mean sum of square of wheat genotypes for stem reserve mobilization (\%) and grain yield per meter square in response to drought and high temperature in peduncle and penultimate internode under timely, late and very late sown condition

\begin{tabular}{|l|c|c|c|c|}
\hline Source of variation & df & \multicolumn{2}{|c|}{ Stem reserve mobilization (\%) } & Grain yield per meter square \\
\hline Replication & & Peduncle & Penultimate internode & \\
\hline Genotype (G) & 2 & $15.984^{* *}$ & $6.653^{* *}$ & $48690.050^{* *}$ \\
\hline Drought Treatment (D) & 7 & $545.720^{* *}$ & $465.881^{* *}$ & $978705.423 * *$ \\
\hline GxD & 4 & $3060.929^{* *}$ & $1296.155^{* *}$ & $3763527.001 * *$ \\
\hline Sowing Time (S) & 28 & $0.817^{* *}$ & $141.216^{* *}$ & $115109.931 * *$ \\
\hline GxS & 2 & $262.680^{*}$ & $107.530^{* *}$ & $448805.668^{* *}$ \\
\hline DxS & 14 & $0.376^{* *}$ & $13.769^{* *}$ & $7862.076^{* *}$ \\
\hline GxDxS & 8 & $14.619^{* *}$ & $5.550^{* *}$ & $13767.091 * *$ \\
\hline Error & 56 & $0.345^{* *}$ & $0.934^{* *}$ & $6047.508^{* *}$ \\
\hline
\end{tabular}

** Significant at $1 \%$ of significance

Table.4 Response of wheat genotypes to drought and high temperature for biomass per square meter (g) under timely, late and very late sown conditions

\begin{tabular}{|c|c|c|c|c|c|c|c|c|c|c|c|c|c|c|c|c|c|c|}
\hline \multirow[t]{3}{*}{ Genotypes } & \multicolumn{6}{|c|}{ Timely Sown } & \multicolumn{6}{|c|}{ Late Sown } & \multicolumn{6}{|c|}{ Very Late Sown } \\
\hline & \multirow[t]{2}{*}{ Control } & \multicolumn{4}{|c|}{ Time of drought application } & \multirow[t]{2}{*}{ Mean $(\mathbf{G})$} & \multirow[t]{2}{*}{ Control } & \multicolumn{4}{|c|}{ Time of drought application } & \multirow[t]{2}{*}{ Mean (G) } & \multirow[t]{2}{*}{ Control } & \multicolumn{4}{|c|}{ Time of drought application } & \multirow[t]{2}{*}{ Mean (G) } \\
\hline & & D40 & D65 & D40+65 & DR & & & D40 & D65 & D40+65 & DR & & & D40 & D65 & D40+65 & DR & \\
\hline AKAW 3717 & 1413.0 & 1259.8 & 1197.3 & 1141.3 & 708.2 & 1143.9 & 940.2 & 752.7 & 621.2 & 550.5 & 238.0 & 620.5 & 570.7 & 481.5 & 379.9 & 281.5 & 150.0 & 372.7 \\
\hline C-306 & 1503.8 & 1313.6 & 1222.8 & 1150.5 & 978.3 & 1233.8 & 1020.1 & 767.9 & 622.3 & 589.1 & 353.3 & 670.5 & 594.0 & 485.3 & 384.8 & 289.7 & 157.1 & 382.2 \\
\hline DHTW-60 & 1576.1 & 1358.7 & 1250.0 & 1177.7 & 1041.8 & 1280.9 & 1313.6 & 911.4 & 751.6 & 616.8 & 529.9 & 824.7 & 729.9 & 538.0 & 465.2 & 375.5 & 262.0 & 474.1 \\
\hline HID-2967 & 1666.8 & 1376.6 & 1259.2 & 1186.4 & 1069.0 & 1311.6 & 1121.2 & 897.8 & 713.6 & 615.8 & 529.9 & 775.7 & 671.7 & 523.4 & 449.5 & 355.4 & 239.7 & 447.9 \\
\hline HTW-11 & 1467.4 & 1304.3 & 1222.8 & 1150.5 & 933.2 & 1215.7 & 1063.6 & 870.1 & 677.7 & 607.6 & 463.6 & 736.5 & 638.6 & 514.7 & 420.1 & 342.9 & 231.5 & 429.6 \\
\hline KUNDAN & 1531.0 & 1340.8 & 1222.8 & 1177.7 & 1005.4 & 1255.5 & 1032.6 & 842.4 & 665.8 & 594.0 & 436.4 & 714.2 & 618.5 & 499.5 & 406.0 & 303.3 & 193.5 & 404.1 \\
\hline WH-730 & 1422.3 & 1277.2 & 1210.3 & 1141.3 & 838.0 & 1177.8 & 987.5 & 759.2 & 621.2 & 581.5 & 282.6 & 646.4 & 607.1 & 495.7 & 394.0 & 297.8 & 172.3 & 393.4 \\
\hline WH-1105 & 1811.4 & 1413.0 & 1259.2 & 1186.4 & 1096.2 & 1353.3 & 1104.9 & 881.0 & 687.5 & 612.5 & 485.3 & 754.2 & 624.5 & 507.6 & 416.8 & 332.1 & 200.5 & 416.3 \\
\hline Mean (D) & 1549.0 & 1330.5 & 1230.6 & 1164.0 & 958.8 & 1246.6 & 1073.0 & 835.3 & 670.1 & 596.0 & 414.9 & 717.9 & 631.9 & 505.7 & 414.5 & 322.3 & 200.8 & 415.0 \\
\hline CD at $5 \%$ & \multicolumn{6}{|c|}{$D=35.24, G=44.58, D x G=99.69$} & \multicolumn{6}{|c|}{$\mathrm{D}=21.04, \mathrm{G}=26.62, \mathrm{DxG}=59.53$} & \multicolumn{6}{|c|}{$D=10.79, G=13.65, D x G=30.53$} \\
\hline
\end{tabular}

D40- Drought at 40 days after sowing (DAS), D65- Drought at 65 DAS, D40+D65- Drought both at 40 and 65 DAS, DR- Complete drought, G-Genotypes and D- Drought 
Fig.1 Response of wheat genotypes to drought and high temperature for stem reserve mobilization in peduncle under timely, late and very late sown conditions

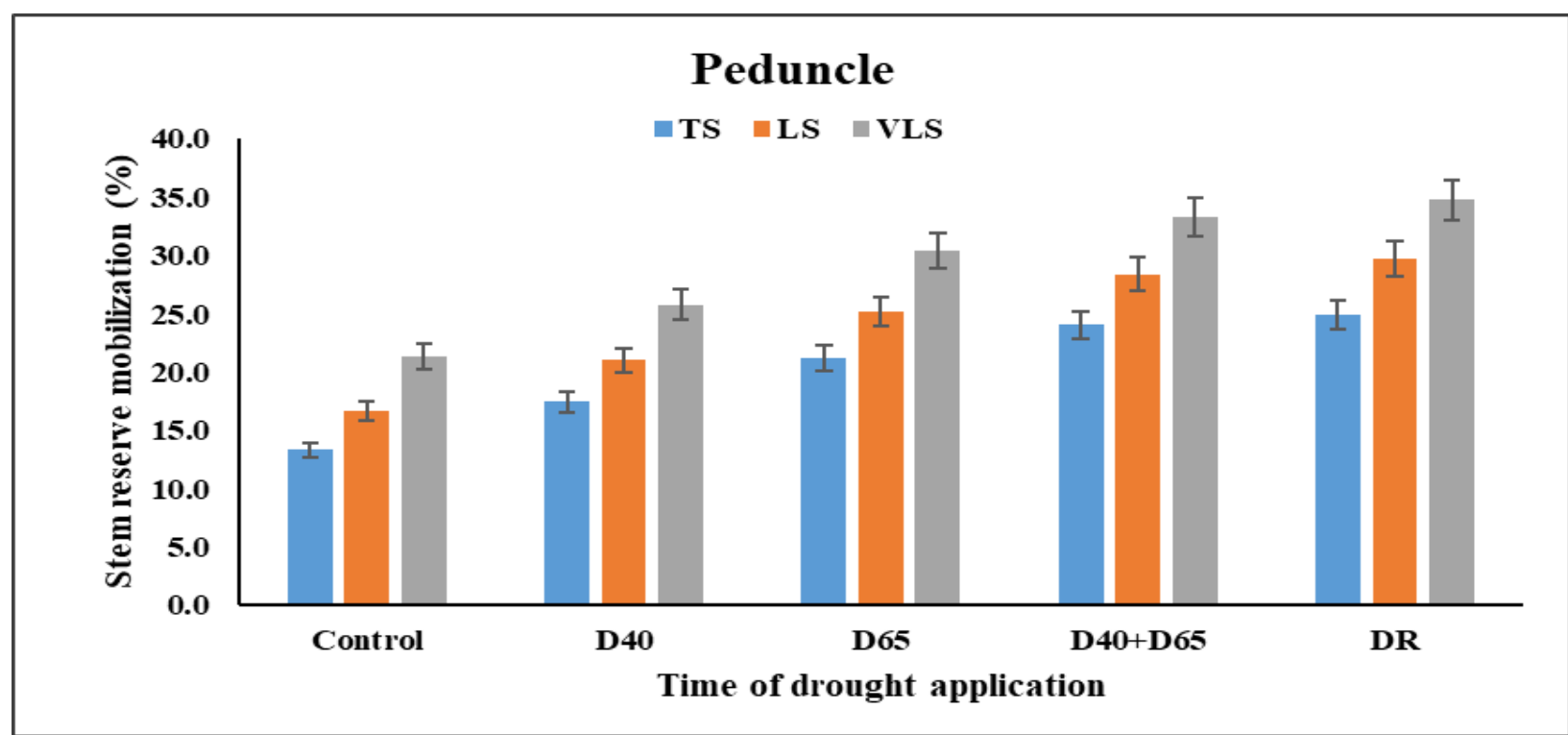

D40- Drought at 40 days after sowing (DAS), D65- Drought at 65 DAS, D40+D65- Drought both at 40 and 65 DAS, DR- Complete drought, TS- Timely sown, LS- Late sown and VLS- Very late sown

Fig.2 Response of wheat genotypes to drought and high temperature for stem reserve mobilization in penultimate internode under timely, late and very late sown conditions

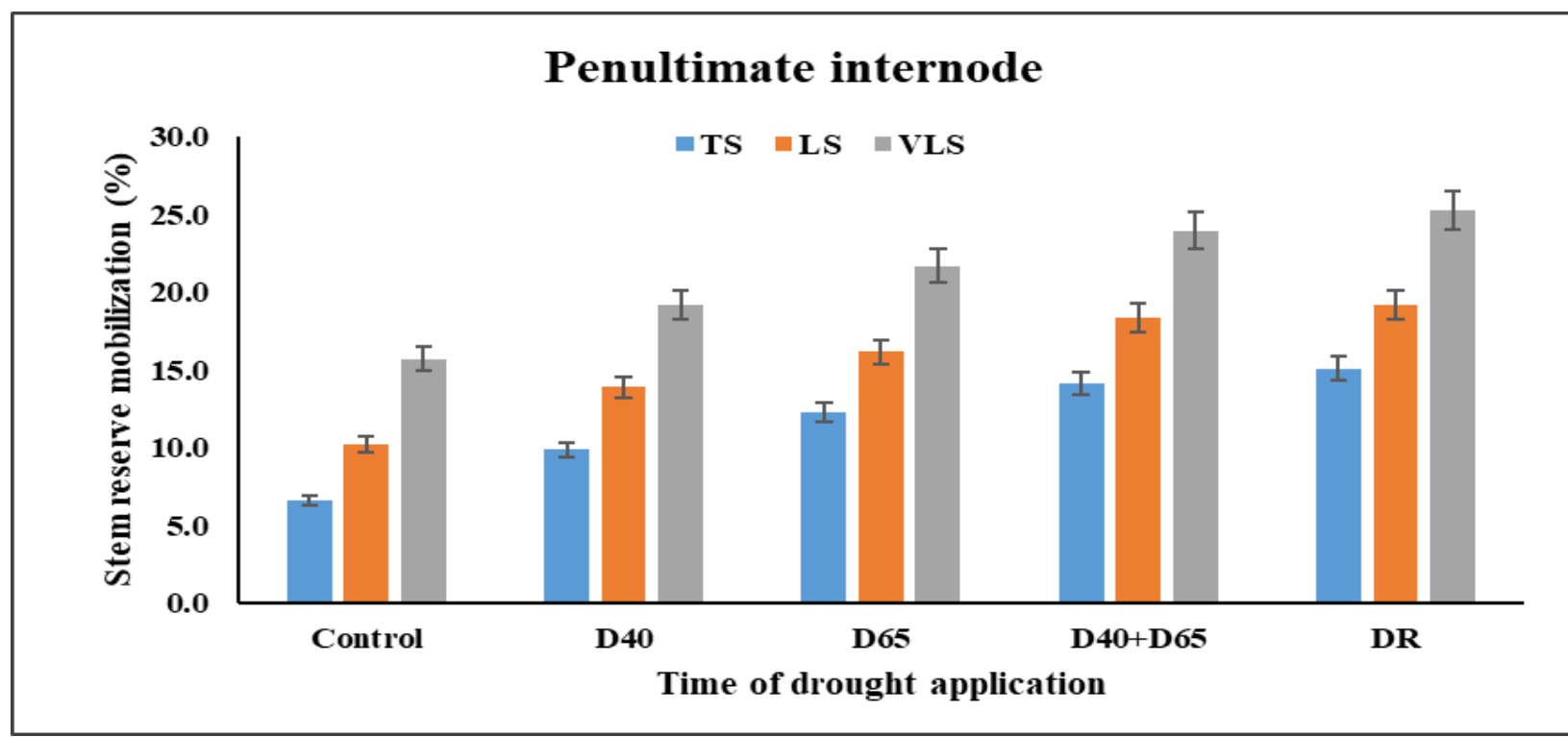

D40- Drought at 40 days after sowing (DAS), D65- Drought at 65 DAS, D40+D65- Drought both at 40 and 65 DAS, DR- Complete drought, TS- Timely sown, LS- Late sown and VLS- Very late sown

Combined effects of delayed sowing and drought stress showed that DHTW-60 (20.4 $\%)$ and HD-2967 (19.9\%) followed by WH$1105(17.4 \%)$ had high penultimate internode reserve mobilization under late sown condition and genotypes DHTW-60 (26.8\%) and HD-2967 (25.9\%) followed by HTW-11 $(23.8 \%)$ under very late sown condition. 
Genotype AKAW-3717 found lowest in average peduncle and penultimate internode reserve mobilization among all genotypes under all drought and delayed sowing conditions. Figure 1 and 2 showed increasing trends in graphical representation for stem reserve mobilization under different drought and sowing condition in peduncle and penultimate internode respectively. Significant difference in stem reserved mobilization at D40, D65, D40+D65 and complete drought situation was observed in peduncle and penultimate internode.

\section{Grain yield per square meter (g)}

Application of drought showed reduction in grain yield per square meter under timely, late and very late sown conditions and maximum reduction in grain yield per square meter were found in complete drought situation (169.4 g) under very late sown condition and minimum reduction in grain yield per square meter were observed in compete drought stress (207.6 g) under timely sown condition (Table 4). Average grain yield per square meter for different drought stress condition ranged from 207.6 to $525.7 \mathrm{~g}$ (timely sown), 208.1 to $402.7 \mathrm{~g}$ (late sown) and 169.4 to $341.7 \mathrm{~g}$ (very late sown). The drought situation of D40+D65, and complete drought resulted significant reduction in grain yield per square meter (355.6 and $207.6 \mathrm{~g}$ ) under timely sown, (327.1 and $208.1 \mathrm{~g}$ ) under late sown and (219.5 and $169.4 \mathrm{~g}$ ) under very late sown condition respectively. Significant difference was found for grain yield per square meter in all genotypes and different drought stress condition with significant interaction effect for drought and genotypes. Average grain yield per square meter for genotypes ranged from 307.6 to $576.3 \mathrm{~g}$ (timely sown), 223.8 to $456.0 \mathrm{~g}$ (late sown) and 192.2 to $350.4 \mathrm{~g}$ (very late sown). Genotype WH-1105 (576.3 g) followed by HD-2967 (490.3 g) and DHTW60 (400.7 g) had maximum grain yield per square meter under timely sown condition whereas, combined effects of heat and drought stress showed that DHTW-60 (456.0 g) and HD-2967 (427.5 g) followed by WH1105 (367.4 g) had maximum grain yield per square meter under late sown condition and genotypes DHTW-60 (350.4 g) and HD-2967 $(427.5 \mathrm{~g})$ followed by HTW-11 (367.4 g) under very late sown condition.

\section{Mean sum of square}

Table 3 showed mean sum of square for stem reserve mobilization and grain yield. These results indicate that there is significant variation due to genotypes $(\mathrm{G})$, drought treatments (D) i.e D40, D65, D40+D65 and complete drought $\&$ due to sowing time $(\mathrm{S})$ i.e timely, late and very late. Interaction effects between genotypes, drought and sowing time was found significant. This indicated that genotypes differed in their response to drought condition and sowing time of the trait under study.

Stored stem reserves serve as a source of carbon for grain filling in wheat, particularly during stress conditions (Wardlaw, 1974) and stem is the alternative source of carbon for grain filling by re-translocating the reserve to maintain reproductive growth under stress conditions (Blum et al., 1994; Wang et al., 2012). Combined effect of stress showed faster remobilization of stem reserve both in peduncle and penultimate internode whereas, peduncle showed faster and higher remobilization in all drought condition and delayed sowing. Genotype DHTW-60, WH1105 \& HD-2967 showed higher SRM at different time of drought application and different sowing condition in peduncle and penultimate internode (Table 1an 2). The results of present investigation are supported by earlier finding of Gupta et al., 2011; Joudi et al., 2012; Zhang et al., 2014). Sharifi et al., (2017) found similar result in wheat 
genotypes under water-deficit treatments with 50 to $80 \%$ higher mobilization than the in well-watered treatments, which indicates that water deficits promoted remobilization. Drought result in increasing mobilization efficiency, expressed as percentage of maximum dry matter mobilized, in the peduncle, penultimate and the lower internodes by 65,11 and $5 \%$, respectively in wheat (Ehdaie et al., 2008). Under heat stress genotypic variation exists for the contribution of stem reserves for grain filling (Yang et al., 2002). Gupta et al., (2011) found higher mobilization of dry matter and mobilization efficiency in the internodes of wheat genotypes C-306 and PBW-343, both under control and stress drought stress conditions, which resulted in enhanced translocation of stem reserves to the grains. Genotype DHTW60, HD-2967, WH-1105 and HTW-11 was found maximum in yield per square meter (Table 4) under drought situation with delayed sowing. Similar findings have also been reported by various workers (Verspreet, 2015; Munjal \& Dhanda, 2016; Zampieri et al., 2017; and Ram et al., 2017a, 2017b). Dwivedi et al., (2017) also reported higher reduction in grain yield $(60.3 \%)$. Maich et al., (2017) reported elevated temperature caused a reduction in grain yield between $6-21 \%$ as compared normal grown varieties. Aynehband et al., (2011) and Wang et al., (2017) reported that grain weight depends on different dates of sowing and water availability.

It was concluded from the above results and discussion, combination of high temperature and drought during grain filling periods is more destructive than individual stress. Faster peduncle and penultimate internode reserve mobilization was responsible for higher gain yield under unfavorable conditions. Genotypes DHTW-60, HD-2967 and WH1105 showed maximum reserve mobilization efficiency and yield in all environment (timely sown, late sown and very late sown) and all treatments (drought at 40 DAS, drought at 80 DAS, Drought at $40+80$ DAS and complete drought) conditions. Genotypes with high remobilization efficiency showed maximum in grain yield per meter square. So, on the basis of this study stem reserve mobilization is best physiological strategy to selection of tolerant and high yielding genotypes for drought and high temperature prone area.

\section{References}

Aynehband, A., Valipoor, M., and Fateh, E. 2011. Stem reserve accumulation and mobilization in wheat (Triticum aestivum L.) as affected by sowing date and NPK. Turkish J Agri Forest, 35, 319-331.

Blum, A., Sinmena, B., Mayer, J., Golan, G. and Shpiler, L. 1994. Stem reserve mobilization supports wheat-grain filling under heat-stress. Australian $J$ Plant Physiol, 21, 771-781.

Cox, M. C., Qualset, C. O. and Rains, D. W. 1986. Genetic variation for nitrogen assimilation and translocation in wheat; Nitrogen translocation in relation to grain yield and protein. Crop Sci, 26, 737-740.

Dreccer, M. F., Van Herwaarden, A. F. and Chapman, S. C. 2009. Grain number and grain weight in wheat lines contrasting for stem water soluble carbohydrate concentration. Field Crops Research, 112, 43-54.

Dwivedi, R., Prasad, S., Jaiswal, B., Kumar, A. and Tiwari, A. 2017. Evaluation of wheat genotypes (Triticum aestivum L.) at Grain Filling Stage for heat tolerance. Inter J Pure App Biosci, 5, 971-975.

Ehdaie, B., Alloush, G. A. and Waines, J. G. 2008. Genotypic variation in linear rate of grain growth and contribution of stem reserves to grain yield in wheat. Field Crops Res, 106, 34-43. 
Ehdaie, B., Alloush, G. A., Madore, M. A. and Waines, J. G. 2006. Genotypic variation for stem reserves and mobilization in wheat: I. Post-anthesis changes in Internode dry matter. Crop Sci, 46, 735-746.

Gupta, A., Kaur, K. and Kaur, N. 2011. Stem Reserve Mobilization and Sink Activity in Wheat under Drought Conditions. American J Plant Sci, 2, 70-77.

Gupta, S. K., Rai, K. N., Singh, P., Ameta, V. L., Gupta, S. K., Jayalekha, A. K., Mahala, R. S., Pareek, S., Swami, M. L., and Verma, Y. S. 2015. Seed set variability under high temperatures during flowering period in pearl millet (Pennisetum glaucum L. (R.) Br.). Field Crop Res, 171, 41-56.

Joudi, M., Ahmadib, A. 1., Mohadi, V., Abbasib, A., Vergauwen, R. and Mohammadi, H. (2012) Comparison of fructan dynamics in two wheat cultivars with different capacities of accumulation and remobilization under drought stress. Physiol Planta, 144, 112.

Maich, R. H., Steffolani, M. E., Rienzo, J. A. and León, A. E. 2017. Association between Grain Yield, Grain Quality and Morpho-physiological Traits along Ten Cycles of Recurrent Selection in Bread Wheat (Triticum aestivum L.). Cereal Res Commun, 45(1), 146-153.

Munjal, R. and Dhanda, S. S. 2016 Assessment of Drought Resistance in Indian Wheat Cultivars for MorphoPhysiological Traits. Ekin J Crop Breed Genet, 2, 74-81.

Pradhan, G. P., Prasad, P. V. V., Fritz, A. K., Kirkham, M. B. and Gill, B. S. 2012. High temperature tolerance in Aegilops species and its potential transfer to wheat. Crop Science, 52, 292-304.

Ram, K., Munjal, R., Sunita and Kumar, N. 2017a. Combined Effects of Drought and High Temperature on Water
Relation Traits in Wheat Genotypes under Late and Very Late Sown Condition. Int J Current Microbiol App sci, 6(8), 567-576.

Ram, K., Munjal, R., Sunita, Pooja and Kumar, N. 2017b. Evaluation of chlorophyll content index and normalized difference vegetation index as indicators for combined effects of drought and high temperature in bread wheat genotypes. Glob J Bio Sci Biotec, 6(3), $528-537$.

Rebetzke, G. J., Van Herwaarden, A.F., Jenkins, C., Weiss, M., Lewis, D., Ruuska, S., Tabe, L., Fettell, N. A. and Richards, R. A. (2008) Quantitative trait loci for water- soluble carbohydrates and associations with agronomic traits in wheat. Australian J Agri Resh, 59, 891-905.

Verspreet, J., Cimini, S., Vergauwen, R., Dornez, E., Locato, V., Le Roy, K. and Gill, K. S. 2015. Fructan metabolism in developing wheat (Triticum aestivum L.) kernels. Plant Cell Physiol, 54, 2047-2057.

Vignjevic, M., Wang, X., Olesen, J. and Wollenweber, B. 2015. Traits in spring wheat cultivars associated with yield loss caused by a heat stress episode after anthesis. J Agro Crop Scie, 201, 32-48.

Wang, J.Y., Xiong, Y.C., Li, F.M., Siddique, K. H. M. and Turner, N. C. 2017. Effects of Drought Stress on Morphophysiological Traits, Biochemical Characteristics, Yield, and Yield Components in Different Ploidy Wheat: A Meta-Analysis. Advan Agro, 143, 139-173.

Wang, X., Cai, J., Liu, F., Jin, M., Yu, H., Jiang, D., Wollenweber, B., Dai, T. and Cao, W. 2012. Pre anthesis high temperature acclimation alleviates the negative effects of post anthesis heat stress on stem stored carbohydrates 
remobilization and grain starch accumulation in wheat. $J$ Plant Physiol, 55, 331-336.

Wardlaw, I. F. 1974. "Temperature control of translocation". In Mechanism of Regulation of Plant Growth, Edited by: Bielske, R. L., Ferguson, A. R. and Cresswell, M. M. 533-538. Wellington, New Zealand: Bulletin of Royal Society of New Zealand.

Yang, J., Sears, R. G., Gill, B. S. and Paulsen, G. M. 2002. Genotypic differences in utilization of assimilate sources during maturation of wheat under chronic heat and heat shock stresses. Euphytica, 125, $179-188$.

Yang, J., Zhang, J., Huang, Z., Zhu, Q. and Wang, L. 2000. Remobilization of carbon reserves is improved by controlled soil-drying during grain filling of wheat. Crop Scie, 40(4), 16451655.

Zampieri1, M., Ceglar, A., Dentener, F. and Toreti, A. 2017. Wheat yield loss attributable to heat waves, drought and water excess at the global, national and subnational scales. Environ Res Letter, 12, 8-19.

Zhang, B., Li, W., Chang, X., Li, R. and Jing, R. (2014) Effects of favorable alleles for water-soluble carbohydrates at grain filling on grain weight under drought and heat stresses in wheat. Plos one, 9, 54-61.

\section{How to cite this article:}

Kirpa Ram, Rajkumar, Sunita and Renu Munjal. 2018. Stem Reserve Mobilization in Relation to Yield under Different Drought and High Temperature Stress Conditions in Wheat (Triticum aestivum L.) Genotypes. Int.J.Curr.Microbiol.App.Sci. 7(04): 3695-3704. doi: https://doi.org/10.20546/ijcmas.2018.704.415 